Western University

Scholarship@Western

Biology Publications

Biology Department

Winter 12-2016

\title{
Freeze tolerance of Cyphoderris monstrosa (Orthoptera: Prophalangopsidae)
}

Jantina Toxopeus

Western University, jtoxopeu@uwo.ca

Jacqueline Lebenzon

Western University, jlebenzo@uwo.ca

Alexander H. Mckinnon

Western University, amckinn9@uwo.ca

Brent J. Sinclair

Western University, bsincla7@uwo.ca

Follow this and additional works at: https://ir.lib.uwo.ca/biologypub

Part of the Biology Commons, Entomology Commons, and the Molecular Biology Commons

Citation of this paper:

Toxopeus, J., Lebenzon, J., McKinnon, A., \& Sinclair, B. (2016). Freeze tolerance of Cyphoderris monstrosa (Orthoptera: Prophalangopsidae). The Canadian Entomologist, 148(6), 668-672. doi:10.4039/tce.2016.21 


\section{THE \\ Canadian Entomologist}

橉圈 CAMBRIDGE

\section{Freeze tolerance of Cyphoderris monstrosa (Orthoptera: Prophalangopsidae)}

\begin{tabular}{|c|c|}
\hline Journal: & The Canadian Entomologist \\
\hline Manuscript ID & TCE-N-2016-004.R1 \\
\hline Manuscript Type: & Note \\
\hline Date Submitted by the Author: & $n / a$ \\
\hline Complete List of Authors: & $\begin{array}{l}\text { Toxopeus, Jantina; University of Western Ontario, Biology } \\
\text { Lebenzon, Jacqueline; University of Western Ontario, Biology } \\
\text { McKinnon, Alexander; University of Western Ontario, Biology } \\
\text { Sinclair, Brent; University of Western Ontario, Department of Biology }\end{array}$ \\
\hline Abstract: & $\begin{array}{l}\text { The great grig, Cyphoderris monstrosa Uhler (Orthoptera: } \\
\text { Prophalangopsidae), is a large ( } 20-30 \mathrm{~mm},>1 \mathrm{~g}) \text {, nocturnal ensiferan that } \\
\text { inhabits montane coniferous forests in northwestern North America. } C \text {. } \\
\text { monstrosa overwinters as a late-instar nymph, but its cold tolerance } \\
\text { strategy has not previously been reported. We collected nymphs from near } \\
\text { Kamloops, British Columbia, in late spring to determine their cold tolerance } \\
\text { strategy. C. monstrosa nymphs were active at low temperatures until they } \\
\text { froze at }-4.6 \pm 0.3^{\circ} \mathrm{C} \text {. The nymphs survived internal ice formation (i.e. are } \\
\text { freeze tolerant), had a lethal temperature between }-9 \text { and }-12^{\circ} \mathrm{C} \text {, and } \\
\text { could survive for between five and ten days at }-6^{\circ} \mathrm{C} \text {. Isolated } C \text {. monstrosa } \\
\text { gut, Malpighian tubules and hind femur muscle tissues froze at } \\
\text { temperatures similar to whole nymphs, and likely inoculate freezing in } \\
\text { vivo. Hemolymph osmolality was } 358 \pm 51 \text { mOsm, with trehalose and } \\
\text { proline comprising approximately } 10 \% \text { of that total. Glycerol was not } \\
\text { detectable in hemolymph from field-fresh nymphs, but accumulated after } \\
\text { freezing and thawing. The control of ice formation and presence of } \\
\text { hemolymph cryoprotectants may contribute to } C \text {. monstrosa freeze } \\
\text { tolerance and overwintering survival. }\end{array}$ \\
\hline
\end{tabular}


Freeze tolerance of Cyphoderris monstrosa (Orthoptera: Prophalangopsidae)

Jantina Toxopeus*, Jacqueline E. Lebenzon, Alexander H McKinnon, Brent J. Sinclair

Department of Biology, University of Western Ontario, 1151 Richmond Street N, London, ON, N6A 5B7, Canada

*Author for correspondence

Jantina Toxopeus

Department of Biology, University of Western Ontario

1151 Richmond Street N

London, ON, N6A 5B7

Canada

Email: jtoxopeu@uwo.ca, Tel: (519) 6612111 ext. 89158, Fax: (519) 661-3935

Jacqueline E. Lebenzon

Email: jlebenzo@uwo.ca, Tel: (519) 6612111 ext. 89158

\section{Alexander H McKinnon}

Email: amckinn9@uwo.ca, Tel: (519) 6612111 ext. 89158

\section{Brent J. Sinclair}

Email: bsincla7@uwo.ca, Tel: (519) 661211 ext.83138 
1 Abstract

2 The great grig, Cyphoderris monstrosa Uhler (Orthoptera: Prophalangopsidae), is a

3 large (20-30 mm, >1 g), nocturnal ensiferan that inhabits montane coniferous forests

4 in northwestern North America. C. monstrosa overwinters as a late-instar nymph, but

5 its cold tolerance strategy has not previously been reported. We collected nymphs

6 from near Kamloops, British Columbia, in late spring to determine their cold

7 tolerance strategy. C. monstrosa nymphs were active at low temperatures until they

8 froze at $-4.6 \pm 0.3{ }^{\circ} \mathrm{C}$. The nymphs survived internal ice formation (i.e. are freeze

9 tolerant), had a lethal temperature between -9 and $-12{ }^{\circ} \mathrm{C}$, and could survive for

10 between five and ten days at $-6{ }^{\circ} \mathrm{C}$. Isolated $C$. monstrosa gut, Malpighian tubules

11 and hind femur muscle tissues froze at temperatures similar to whole nymphs, and

12 likely inoculate freezing in vivo. Hemolymph osmolality was $358 \pm 51 \mathrm{mOsm}$, with

13 trehalose and proline comprising approximately $10 \%$ of that total. Glycerol was not

14 detectable in hemolymph from field-fresh nymphs, but accumulated after freezing

15 and thawing. The control of ice formation and presence of hemolymph

16 cryoprotectants may contribute to C. monstrosa freeze tolerance and overwintering

17 survival. 


\section{Introduction}

The great grig, Cyphoderris monstrosa Uhler (Orthoptera:

Prophalangopsidae), is a large $(20-30 \mathrm{~mm}$ long, adults $>1.5 \mathrm{~g})$ ensiferan that inhabits montane coniferous forests of western North America (Morris and Gwynne 1978; Kumala et al. 2005). C. monstrosa is nocturnal, emerging from below-ground burrows and climbing conifers to feed on staminate cones (Caudell 1904; Morris and Gwynne 1978; Ladau 2003). Males sing after dusk via tegminal stridulation (Morris and Gwynne 1978) from late May or early June until late August (Mason 1996). Cyphoderris spp. are active at much lower temperatures than is typical for acoustic insects, singing at temperatures near $0{ }^{\circ} \mathrm{C}$ (Morris and Gwynne 1978; Dodson et al. 1983; Morris et al. 1989). C. monstrosa are thought to overwinter as late-instar nymphs in burrows below the leaf litter layer (Gwynne 1995), but nothing is known about their low temperature biology.

Insects employ two dominant strategies to survive subzero temperatures: freeze avoidant insects depress the temperature at which their fluids freeze, but die upon ice formation, while freeze tolerant insects can withstand internal ice formation. Although orthopteran eggs are freeze avoidant (e.g. Hao and Kang 2004), many nymphs and adults are freeze tolerant (e.g. Alexander 1967). The mechanisms underlying freeze tolerance are unclear, but many freeze-tolerant insects accumulate low molecular weight cryoprotectants, including the disaccharide trehalose and free amino acid proline, both detected in hemolymph of freeze-tolerant New Zealand 
alpine weta, Hemideina maori Pictet \& Saussure (Orthoptera: Anostosmatidae) (Neufeld and Leader 1998). Many freeze-tolerant insects accumulate glycerol (Lee 2010), but this cryoprotectant has not been detected in freeze-tolerant orthopterans (Ramløv et al. 1992; McKinnon 2015). Regulating the location and temperature of ice nucleation is thought to be essential for insect freeze tolerance (Zachariassen and Kristiansen 2000). These ice nucleators may be endogenous (e.g. proteins) or exogenous (e.g. ice nucleating-active bacteria or ice crystals), and can be located in the hemolymph (e.g. H. maori; Sinclair et al. 1999) and tissues (e.g. the Malpighian tubules and fat bodies of E. solidaginis; Mugnano et al. 1996).

Here, we characterize the cold tolerance strategy, the lower lethal limits, likely sites of ice nucleation, and common low molecular weight cryoprotectants of the overwintering stage of $C$. monstrosa.

\section{Materials \& Methods}

We collected 40 nymphs by hand from tree trunks in pine forests near Kamloops, British Columbia $\left(50.45^{\circ} \mathrm{N}, 120.07^{\circ} \mathrm{W}\right.$, c. $1000 \mathrm{~m}$ a.s.1) from 27 May -2 June 2015. During this period, the air temperature ranged from 7.3 to $29.3{ }^{\circ} \mathrm{C}$, with a daily mean of $17.8{ }^{\circ} \mathrm{C}$ (Environment Canada 2015). We placed nymphs in $100 \mathrm{ml}$ perforated plastic containers, with apple pieces for food. We shipped the animals on ice to the University of Western Ontario, where we maintained them for 2-6 weeks at 
$614{ }^{\circ} \mathrm{C}$ until use in experiments. Nymphs fed in captivity, thus apple pieces were 62 replaced weekly.

63

64

65

66

67

68

69

70

71

72

73

74

75

76

77

78

79

80

81

82

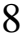

For low temperature exposures, we placed nymphs (wet mass range: 0.3-1.48 g) in $35 \mathrm{ml}$ plastic vials in contact with a type $\mathrm{T}$ (copper-constantan) thermocouple and cooled them at $0.25^{\circ} \mathrm{C} \mathrm{min}-1$ to the target temperature in an aluminum block through which $50 \%$ methanol was circulated from a programmable refrigerated circulator (Proline RP 55, Lauda, Wurzburg, Germany). We monitored the temperature from the thermocouple using PicoLog software via a Picotech TC-08 thermocouple interface (Pico Technology, Cambridge, UK). Our general approach to characterizing cold tolerance is described by Sinclair et al. (2015). In all cases, we rewarmed the nymphs at $0.25{ }^{\circ} \mathrm{C} \min ^{-1}$ to $4{ }^{\circ} \mathrm{C}$, weighed them (fresh mass $\pm 0.01 \mathrm{~g}$ ), and transferred them to individual $100 \mathrm{ml}$ containers with apple pieces at $15{ }^{\circ} \mathrm{C}$ for recovery. Nymphs were considered 'alive' if they could stand and move in a coordinated fashion $48 \mathrm{~h}$ after thawing. Because developmental stage of orthopterans can modify parameters such as metabolic composition (e.g. Anand and Lorenz 2008), we restricted subsequent experiments to larger nymphs $(>0.9 \mathrm{~g})$. point, SCP), we cooled nymphs in $35 \mathrm{ml}$ plastic vials as described above, and recorded the lowest temperature before the exotherm due to ice formation (Sinclair et al. 2015). The survival of these nymphs was monitored (details below). To determine 
83 the critical thermal minimum $\left(\mathrm{CT}_{\min }\right)$, or the temperature at which the nymphs

84 entered chill coma, we cooled six nymphs from $25^{\circ} \mathrm{C}$ to the SCP as described

85 previously (MacMillan and Sinclair 2011). Nymphs were monitored continuously,

86 and the $\mathrm{CT}_{\min }$ was the temperature at which nymphs could no longer exhibit

87 coordinated movement in response to probing. We determined cold tolerance strategy

88 by monitoring survival of nymphs held for $1.5 \mathrm{~h}$ at $-4{ }^{\circ} \mathrm{C}$ (unfrozen) or $-6^{\circ} \mathrm{C}$ (frozen),

89 with freezing confirmed by detection of the SCP exotherm of each nymph. We

90 considered them freeze tolerant if they survived both temperatures, freeze avoidant if

91 they survived at $-4{ }^{\circ} \mathrm{C}$ but not $-6^{\circ} \mathrm{C}$, or chill-susceptible if they were killed by

92 exposure both temperatures. We determined the lethal temperature by determining

93 survival of nymphs exposed to temperatures between $-9{ }^{\circ} \mathrm{C}$ and $-16^{\circ} \mathrm{C}$ for $1.5 \mathrm{~h}$. To

94 determine lethal time, we monitored survival of nymphs kept frozen at $-6{ }^{\circ} \mathrm{C}$ for time

95 periods between $1.5 \mathrm{~h}$ and $10 \mathrm{~d}$, and subsequently thawed. Each nymph was exposed

96 to only one cold treatment.

97

98

100

101

102

103

To identify likely sites of ice nucleation, we compared the SCP of hemolymph and several excised tissues (foregut, midgut, hindgut, Malpighian tubules, fat bodies, and hind femur muscle) to whole body SCP. We extracted $4 \mu \mathrm{l}$ of hemolymph from each of three nymphs (mass 1.16, 1.25, and $1.48 \mathrm{~g}$ ) using a $20 \mu \mathrm{l}$ pipette, and diluted it with $12 \mu 13 \%$ ascorbic acid to prevent coagulation (McKinnon 2015). We dissected tissues from the same three nymphs, and placed them in $20 \mu 13 \%$ ascorbic 
104 acid. We cooled hemolymph, tissue samples, and $20 \mu 13 \%$ ascorbic acid in $1.7 \mathrm{ml}$

105 microcentrifuge tubes at $0.25^{\circ} \mathrm{C} \min ^{-1}$ from $4{ }^{\circ} \mathrm{C}$ to $-30{ }^{\circ} \mathrm{C}$, with thermocouples

106 attached to the external surface of tubes to detect temperature. We compared the

107 mean SCP of hemolymph (in $3 \%$ ascorbic acid) to $3 \%$ ascorbic acid alone, as well

108 as the mean SCP of hemolymph and each tissue to whole-body SCP using a one-way

109 ANOVA with planned contrasts in $\mathrm{R}$ version 3.0.3 (R Core Team 2013). Means are

110 reported \pm s.e.m.

111

112 We also determined total hemolymph osmolality using a nanolitre osmometer

113 (Otago Osmometers, Dunedin, New Zealand), as described previously (Crosthwaite

114 et al. 2011). To quantify potential low molecular weight cryoprotectants in the

115 hemolymph, we measured free proline (Carillo and Gibon 2011), glycerol

116 (Crosthwaite et al. 2011) and trehalose (Tennessen et al. 2014) in $4 \mu$ l samples of

117 hemolymph from three to eight nymphs (mass range: 0.9-1.48 g) using enzymatic

118 spectrophotometric assays. Hemolymph was extracted from untreated nymphs, as

119 well as nymphs that were frozen at $-6^{\circ} \mathrm{C}$ for $1 \mathrm{~h}$. Mean osmolality and cryoprotectant

120 concentrations are reported \pm s.e.m.

121

122 Results \& Discussion

123 Cyphoderris monstrosa nymphs remained active as they were cooled, until

124 they froze at a mean SCP of $-4.6 \pm 0.3{ }^{\circ} \mathrm{C}$ (range: -2.4 to $-6.8^{\circ} \mathrm{C}$ ). All C. monstrosa

125 nymphs survived exposure to $-4{ }^{\circ} \mathrm{C}\left(N=4\right.$, unfrozen) and $-6{ }^{\circ} \mathrm{C}(N=4$, frozen $)$, thus we 
126 conclude that they are freeze-tolerant. Most (75\%) C. monstrosa survived being

127 frozen at $-6{ }^{\circ} \mathrm{C}$ for 5 days (Fig. 1a), demonstrating survival of equilibrium ice

128 formation (which can take several hours in large Orthoptera; Ramløv and Westh

129 1993). However, they did not survive acute $(1.5 \mathrm{~h})$ exposures at or below $-12{ }^{\circ} \mathrm{C}$ (Fig.

130 1b). This pattern is similar to other freeze-tolerant ensiferans, such as H. maori

131 (Ramløv et al. 1992), that freeze at moderate subzero temperatures, but have a

132 relatively high lower lethal temperature (Sinclair et al. 2003).

133

134 The mean fresh mass of C. monstrosa nymphs was $0.95 \pm 0.08 \mathrm{~g}$ (range: 0.30

135 to $1.52 \mathrm{~g}$ ), and SCP was independent of fresh mass (linear regression, $F_{1,21}=0.207, p$

$136=0.65$ ), suggesting that ice formation is initiated by ice nucleating agents (Sinclair $e t$

137 al. 2009). The relationship between dry mass and SCP could be examined to verify

138 this trend (e.g. Ditrich and Koštál 2011). C. monstrosa hemolymph froze at $-8.5^{\circ} \mathrm{C}, 8$

$139{ }^{\circ} \mathrm{C}$ higher than the ascorbic acid anticoagulant (Fig. 2), indicating the presence of a

140 hemolymph ice nucleator (cf. Sømme 1986; Sinclair et al. 1999), although the low

141 SCP of hemolymph suggests that it is not the source of the high SCP we observe in

142 the whole animal. Fat body did not substantially increase the SCP of ascorbic acid,

143 but gut tissues, hind femur muscle and Malpighian tubules in ascorbic acid froze at

144 temperatures similar to whole-body SCP (Fig. 2). Thus, it appears that although there

145 is a nucleating agent in the hemolymph, ice formation is initiated by one or more of

146 these tissues, similar to the ice-nucleating Malpighian tubules and fat bodies of $E$.

147 solidaginis (Mugnano et al. 1996). 
$150(N=4)$. This is lower than that of other freeze tolerant ensiferans, H. maori (700

151 mOsm; Ramløv 1999) and Gryllus veletis Alexander \& Bigelow (Orthoptera:

152 Gryllidae) (615 mOsm; McKinnon 2015). C. monstrosa hemolymph contained $17.4 \pm$

$1533.2 \mathrm{mM}$ trehalose $(N=4)$ and $12.7 \pm 2.6 \mathrm{mM}$ proline $(N=8)$, accounting for

154 approximately $10 \%$ of total hemolymph osmolality. The concentrations of these

155 cryoprotectants are lower than in H. maori (Ramløv et al. 1992; Neufeld and Leader

156 1998) and G. veletis (McKinnon 2015). Like G. veletis and H. maori, we detected no

157 hemolymph glycerol in field-fresh nymphs $(N=3)$. However, hemolymph sampled 2

158 to 4 weeks after the nymphs had been frozen at $-6{ }^{\circ} \mathrm{C}$ contained $14.6 \pm 5.7 \mathrm{mM}$

159 glycerol $(N=3)$. No such changes in hemolymph concentrations of trehalose or proline

160 were observed after freezing. The increase in glycerol suggests that $C$. monstrosa

161 cryoprotectant composition is plastic, and that they may also be able to enhance

162 freeze tolerance in response to short cold exposures, such as frosts in the fall or late

163 spring (cf. Marshall and Sinclair 2015). Thus, although the hemolymph osmolality we

164 measured in C. monstrosa was not high in our spring-collected specimens, there is

165 potential for an increase in hemolymph osmolality prior to or during the winter

166 months, which may support lower lethal temperatures and tolerance to longer

167 durations frozen than we observed in this study. 
169 To our knowledge, this is the first report of freeze tolerance in

170 Prophalangopsidae. The minimum air temperature in Kamloops during the 2014-2015

171 winter was $-19.6{ }^{\circ} \mathrm{C}$ (Environment Canada 2015), well below the lethal temperature

172 of $C$. monstrosa nymphs. However, their overwintering habitat is likely buffered by

173 snow cover (Petty et al. 2015), such that burrow temperatures likely do not approach

174 these low air temperatures. Future investigations could determine whether $C$.

175 monstrosa exhibits seasonal plasticity in freeze tolerance, and which mechanisms

176 (e.g. cryoprotectant accumulation) drive this plasticity.

177

178 Acknowledgements

179 Thanks to Andrew Mason, Terrence Chang and Kevin Judge for collection advice,

180 and two anonymous referees for comments that improved the ms. This research was

181 supported by a National Sciences and Engineering Research Council (NSERC)

182 Discovery Grant to BJS and an Orthopterists' Society Theodore J. Cohn Research

183 Fund grant to JT. JT was supported by an NSERC Canada Graduate Scholarship, and 184 AHM by an Ontario Graduate Scholarship. 


\section{$185 \quad$ References}

186 Alexander, G. 1967. Cold hardiness in overwintering juvenile grasshoppers.

187

188

189

190

191

192 Entomological News, 78: 147-154.

Anand, A.N. and Lorenz, M.W. 2008 Age-dependent changes of fat body stores and the regulation of fat body lipid synthesis and mobilisation by adipokinetic hormone in the last larval instar of the cricket, Gryllus bimaculatus. Journal of Insect Physiology, 54: 1404-1412.

Carillo, P. and Gibon, Y. 2011. Protocol: extraction and determination of proline. PrometheusWiki.

Caudell, A.N. 1904. The genus Cyphoderris. Journal of the New York Entomological Society, 12: 47-53.

Crosthwaite, J.C., Sobek, S., Lyons, D.B., Bernards, M.A., and Sinclair, B.J. 2011. The overwintering physiology of the emerald ash borer, Agrilus planipennis Fairmaire (Coleoptera: Buprestidae). Journal of Insect Physiology, 57: 166173.

Ditrich, T. and Koštál, V. 2011. Comparative analysis of overwintering physiology in nine species of semi-aquatic bugs (Heteroptera: Gerromorpha). Physiological Entomology, 36: 261-270.

Dodson, G.N., Morris, G.K., and Gwynne, D.T. 1983. Mating behavior of the primitive orthopteran genus Cyphoderris (Haglidae). In Orthopteran mating systems: sexual competition in a diverse group of insects. Edited by D.T. Gwynne and G.K. Morris. Westview Press, Inc., Boulder, USA. Pp. 305-318. 
207 Environment Canada 2015. Historical climate data, Kamloops, British Columbia 208 [online]. Available from http://climate.weather.gc.ca/index_e.html [accessed 4 February 2016].

210 Gwynne, D.T. 1995. Phylogeny of the Ensifera (Orthoptera): a hypothesis supporting multiple origins of acoustical signalling, complex spermatophores and maternal care in crickets, katydids, and weta. Journal of Orthoptera Research, 203-218.

214 Hao, S.-G. and Kang, L. 2004. Supercooling capacity and cold hardiness of the eggs of the grasshopper Chorthippus fallax (Orthoptera: Acrididae). European Journal of Entomology, 101: 231-236.

217 Kumala, M., McLennan, D.A., Brooks, D.R., and Mason, A.C. 2005. Phylogenetic relationships within hump-winged grigs, Cyphoderris (Insecta, Orthoptera, Tettigonioidea, Haglidae). Canadian Journal of Zoology, 83: 1003-1011.

Ladau, J. 2003. Territoriality and singing-site preferences in the cricket, Cyphoderris monstrosa (Orthoptera: Haglidae) in western North America. Entomological News, 114: 197-204.

Lee, R.E. 2010. A primer on insect cold-tolerance. In Low Temperature Biology of Insects. Edited by D.L. Denlinger and R.E. Lee. Cambridge University Press, New York, USA. Pp. 3-34.

MacMillan, H.A. and Sinclair, B.J. 2011. The role of gut in insect chilling injury: cold-induced disruption of osmoregulation in the field fall cricket, Gryllus pennsylvanicus. The Journal of Experimental Biology, 214: 726-734. 
229 Marshall, K.E. and Sinclair, B.J. 2015. The relative importance of number, duration and intensity of cold stress events in determining survival and energetics of an overwintering insect. Functional Ecology, 29: 357-366.

Mason, A.C. 1996. Territoriality and the function of song in the primitive acoustic insect Cyphoderris monstrosa (Orthoptera: Haglidae). Animal Behaviour, 51: 211-214.

McKinnon, A.H. 2015. Freeze tolerance in the spring field cricket, Gryllus veletis. MSc thesis. University of Western Ontario, London, Canada.

Morris, G.K. and Gwynne, D.T. 1978. Geographical distribution and biological observations of Cyphoderris (Orthoptera: Haglidae) with a description of a new species. Psyche, 85: 147-167.

Morris, G.K., Gwynne, D.T., Klimas, D.E., and Sakaluk, S.K. 1989. Virgin male mating advantage in a primitive acoustic insect (Orthoptera: Haglidae). Journal of Insect Behavior, 2: 173-185.

Mugnano, J.A., Lee, R.E., and Taylor, R.T. 1996. Fat body cells and calcium phosphate spherules induce ice nucleation in the freeze-tolerant larve of the gall fly Eurosta solidaginis (Diptera, Tephritidae). The Journal of Experimental Biology, 199: 465-471.

Neufeld, D.S. and Leader, L.P. 1998. Freezing survival by isolated Malpighian tubules of the New Zealand alpine weta Hemideina maori. Journal of Experimental Biology, 201: 227-236. 
250 Petty, S.K., Zuckerberg, B., and Pauli, J.N. 2015. Winter conditions and land cover 251 structure the subnivium, a seasonal refuge beneath the snow. PLoS One, 10: $252 \quad \mathrm{e} 0127613$.

253 R Core Team 2013. R: A Language and Environment for Statistical Computing. R 254 Foundation for Statistical Computing, Vienna, Austria. http://www.R$255 \quad$ project.org

256 Ramløv, H. 1999. Microclimate and variations in haemolymph composition in the 257 freezing-tolerant New Zealand alpine weta Hemideina maori Hutton 258 (Orthoptera: Stenopelmatidae). Journal of Comparative Physiology B, 169: 259 224-235.

260 Ramløv, H., Bedford, J., and Leader, J. 1992. Freezing tolerance of the New Zealand 261 alpine weta, Hemideina maori Hutton [Orthoptera; Stenopelmatidae]. Journal 262 of Thermal Biology, 17: 51-54.

263 Ramløv, H. and Westh, P. 1993. Ice formation in the freeze tolerant alpine weta 264 Hemideina maori Hutton (Orthoptera, Stenopelmatidae). Cryo-Letters, 14: $265 \quad 169-176$.

266 Sinclair, B.J., Addo-Beddiako, A., and Chown, S.L. 2003. Climatic variability and 267 the evolution of insect freeze tolerance. Biological Reviews, 78: 181-195. 268 Sinclair, B.J., Alvarado, L.E.C., and Ferguson, L.V. 2015. An invitation to measure 269 insect cold tolerance: methods, approaches, and workflow. Journal of Thermal Biology, 53: 180-197. 
271 Sinclair, B.J., Gibbs, A.G., Lee, W.-K., Rajamohan, A., Roberts, S.P., and Socha, J.J. 272 2009. Synchrotron $\mathrm{x}$-ray visualisation of ice formation in insects during lethal and non-lethal freezing. PLoS One, 4: e8259.

274 Sinclair, B.J., Worland, M.R., and Wharton, D.A. 1999. Ice nucleation and freezing tolerance in New Zealand alpine and lowland weta, Hemideina spp. (Orthoptera; Stenopelmatidae). Physiological Entomology, 24: 56-63.

277 Sømme, L. 1986. Tolerance to low temperatures and desiccation in insects from Andean paramos. Arctic and Alpine Research, 18: 253-259. studying metabolism in Drosophila. Methods, 68: 105-115.

Zachariassen, K.E. and Kristiansen, E. 2000. Ice nucleation and antinucleation in 282 nature. Cryobiology, 41: 257-279. 
Toxopeus 16

\section{Figure Legends}

287

288 Figure 1. Survival of C. monstrosa nymphs $48 \mathrm{~h}$ after being frozen for different

289 periods of time at $-6^{\circ} \mathrm{C}(\mathrm{A})$ or at different temperatures for $1.5 \mathrm{~h}(\mathrm{~B}) . N=4$ for each

290 temperature and time point. Survival curves were calculated using a generalized

291 linear model.

292

293 Figure 2. Mean \pm s.e.m. SCP of whole $C$. monstrosa nymphs, $20 \mu 13 \%$ ascorbic

294 acid, hemolymph diluted 1:3 with $3 \%$ ascorbic acid, and tissues (c. $10 \mathrm{mg}$ ) in $20 \mu \mathrm{l}$

$2953 \%$ ascorbic acid. $N=23$ for whole body SCP, $N=3$ for all other samples. Different

296 letters indicate significant differences $(\alpha=0.05)$ in SCP (ANOVA with planned

297 contrasts: $\left.F_{8,21}=5.671, p<0.001\right)$. 


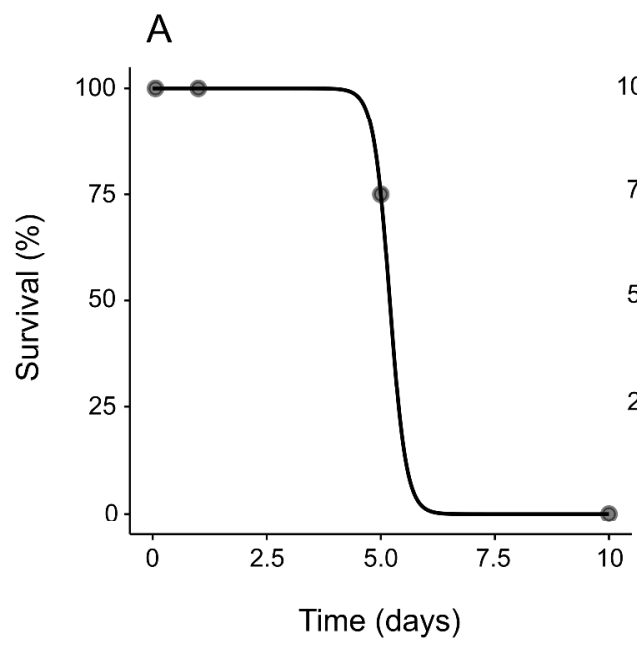

B

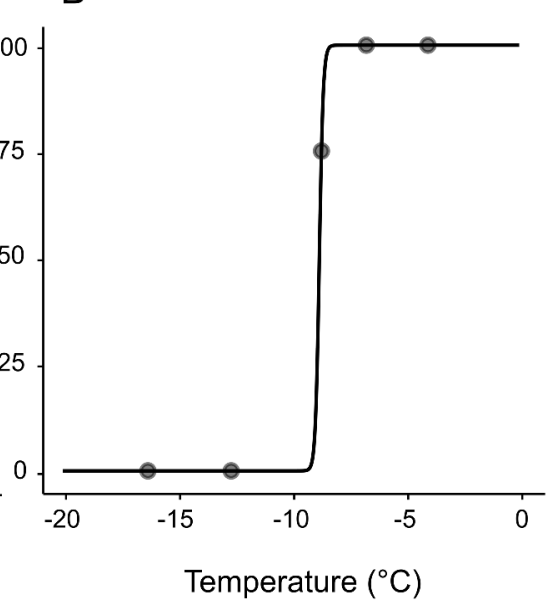

. Survival of $C$. monstrosa nymphs $48 \mathrm{~h}$ after being frozen for different periods of time at $-6^{\circ} \mathrm{C}(\mathrm{A})$ or at different temperatures for $1.5 \mathrm{~h}(\mathrm{~B}) . \mathrm{N}=4$ for each temperature and time point. Survival curves were calculated using a generalized linear model.

$1979 \times 1013 \mathrm{~mm}$ (96 x 96 DPI) 


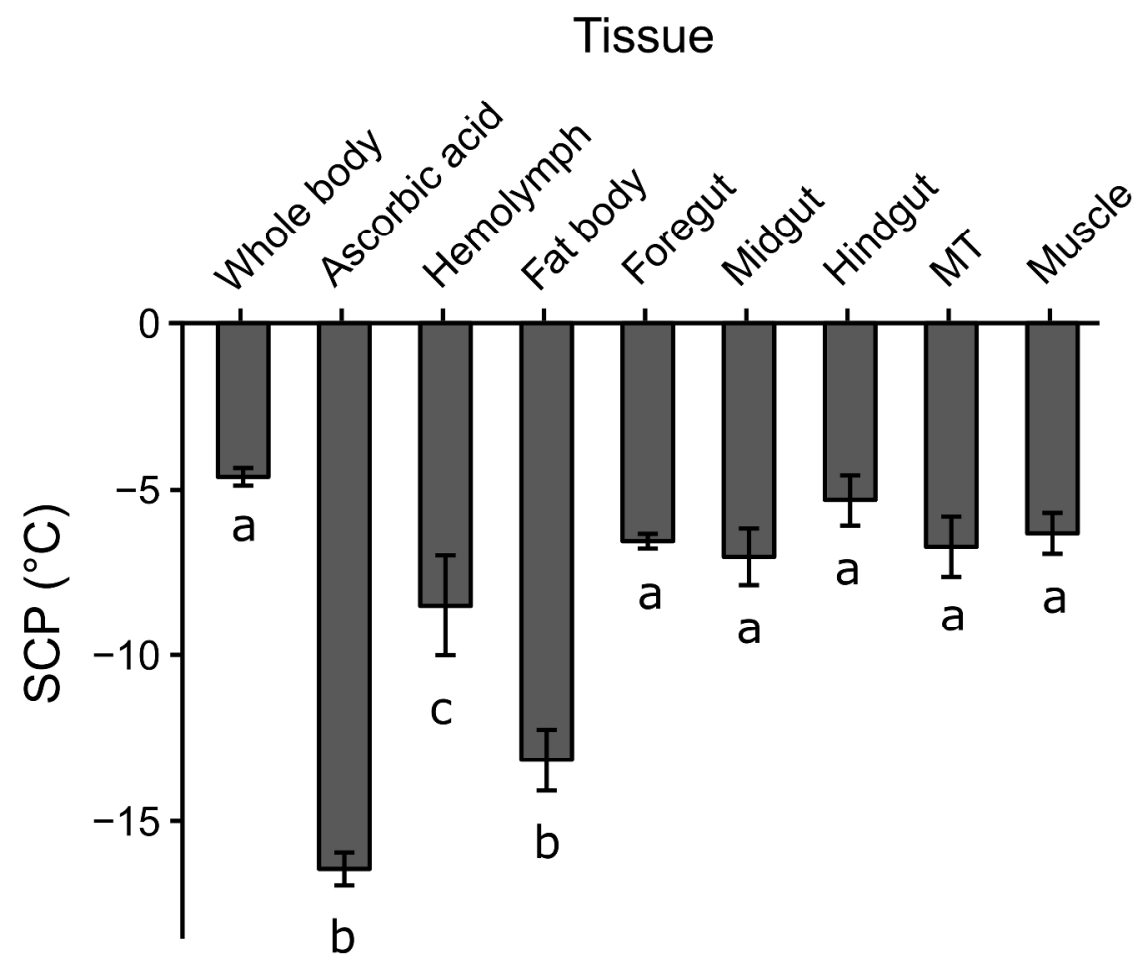

Mean \pm s.e.m. SCP of whole $C$. monstrosa nymphs, $20 \mu \mathrm{l} 3 \%$ ascorbic acid, hemolymph diluted $1: 3$ with $3 \%$ ascorbic acid, and tissues (c. $10 \mathrm{mg}$ ) in $20 \mu \mathrm{l} 3 \%$ ascorbic acid. $\mathrm{N}=23$ for whole body SCP, $\mathrm{N}=3$ for all other samples. Different letters indicate significant differences $(a=0.05)$ in SCP (ANOVA with planned contrasts:

$\mathrm{F} 8,21=5.671, \mathrm{p}<0.001)$

$941 \times 757 \mathrm{~mm}(96 \times 96 \mathrm{DPI})$ 